\title{
Poluição e doenças ocupacionais pulmonares
}

\author{
EDUARDO ALGRANTI ${ }^{1}$
}

Foram apresentados quatro trabalhos sobre Doenças O cupacionais Pulmonares, sendo dois experimentais e dois clínicos, e cinco trabalhos sobre Poluição, sendo três experimentais e dois epidemiológicos.

\section{Doenças Ocupacionais Pulmonares}

Os trabalhos experimentais de DOP são do grupo do Laboratório de Fisiologia Respiratória da UFRJ e referem-se ao estudo da caracterização das propriedades mecânicas pulmonares em pulmões de ratos, 20 dias após injeção intratraqueal de sílica, comparada com injeções de soro fisiológico (Silva GH e col.). Um segundo trabalho aborda os mecanismos celulares implicados nas alterações funcionais, comparando-se ratos normais com uma linhagem de ratos deficientes em CD95 (Falcão H e col.).

No presente, há uma relativa pobreza em trabalhos que procurem desvendar os mecanismos patogênicos das alterações conseqüentes à exposição à sílica. 0 principal motivo prende-se à relativa perda de interesse em países desenvolvidos, pelo fato de a silicose não ter importância epidemiológica de anos passados. Porém, no Brasil, a situação é diversa, sendo a silicose a pneumoconiose mais prevalente. 0 estudo dos mecanismos celulares implicados no processo da doença é um dos caminhos que podem indicar possibilidades terapêuticas, fato de grande relevância. Ratos deficientes em Fas (CD95) não apresentavam alterações histopatológicas e/ ou mecânicas do tecido pulmonar. Ratos não deficientes apresentaram infiltrações neutrofílicas, obstruções intrabrônquicas e atelectasias, que se traduziam funcionalmente por um aumento da resistência elástica pulmonar. Estes fenômenos são precoces e, possivelmente, compatíveis com exposições humanas a altas concentrações de sílica.

Os trabalhos clínicos são familiares aos pneumologistas interessados na área, pois haviam sido apresentados no último Congresso Brasileiro. 0 tema de avaliação das trocas gasosas, em repouso e exercício em pacientes portadores de asbestose apresentado pelo Grupo Interinstitucional de Estudos das Doenças Associadas ao Asbesto (Unicamp, USP, U nifesp) (Sette AA e col.) é de grande importância na avaliação da disfunção e incapacidade. O Laboratório de Exercício

1. Presidente da Comissão de Poluição e Doenças O cupacionais da SBPT; Divisão de Medicina - Fundacentro, São Paulo, SP. E-mail: algranti@usp.br da Unifesp, já há anos, contribui para um melhor entendimento destas questões. O DLCO não costuma estar afetado nas fases iniciais da asbestose, porém não há dados no resumo que correlacionem as trocas gasosas com a leitura radiológica ou os achados tomográficos. Interessante que apenas $50 \%$ dos casos com DLCO de repouso alterado apresentavam 0 aumento na diferença $(A-a) O_{2}$ de repouso e exercício. U ma maior amostragem, com controle para as variáveis de confusão, certamente será um excelente contribuição para um melhor estabelecimento da disfunção associada à asbestose.

A spectos ligados à inflamação de vias aéreas na exposição a sílica foram abordados pelo grupo de Pneumologia da UFRJ (Lago P e col.). Foram obtidas amostras de escarro induzido de 33 trabalhadores de pedreira e 9 controles. Trabalhadores e controles incluídos na análise não apresentavam asma, infecções respiratórias recentes e não eram fumantes. Dos 33, 13 eram administrativos e 20 da área de produção. A neutrofilia de escarro foi significativamente maior nos trabaIhadores comparados com os controles, porém, inesperadamente não houve diferença entre trabalhadores da área administrativa e os da área de produção. Trabalhadores com mais tempo de atividade apresentavam maior neutrofilia no escarro. A sinalização de uma associação entre neutrofilia no escarro e tempo de exposição merece ser melhor explorada.

\section{POLUIÇÃO}

Os trabalhos sobre Poluição seguem uma linha de pesquisa sólida iniciada pelo Laboratório de Poluição Experimental do Ar da FMUSP.

Os trabalhos experimentais abordaram o estresse oxidativo das $\mathrm{PM}_{10}$ sobre o epitélio de palato de sapos (Macchione $\mathrm{M}$ e col.) e 0 efeito do formaldeído no transporte mucociliar (Fló-Neyret $\mathrm{C}$ e col.). A través da análise de mucinas e glutathion, demonstrou-se que a exposição a $\mathrm{PM}_{10}$ associa-se a um significativo efeito oxidativo sobre o epitélio ciliado, assim como o formaldeído, em concentração crescente, associou-se a uma diminuição do transporte mucociliar em preparações de palato de sapos. Ambos tratam de efeitos agudos dos poluentes nas vias aéreas que, nem sempre, podem ser extrapolados para situações clínicas de exposições continuadas, uma vez que há mecanismos de balanço que se opõem ao efeito deletério dos poluentes. 
U m trabalho interessante apresentado pela U nifesp sobre o efeito da conservação de muco humano em diferentes temperaturas mostra que ele não perde suas propriedades (velocidade de transporte) quando conservado a um temperatura próxima ao ambiente (Gastaldi AC e col.).

A influência da exposição a poluentes ambientais em admissões por doença coronariana isquêmica em um hospital especializado da região urbana de São Paulo foi avaliada em um período de dois anos (1994-1995) (Lin CA e col.). A través de técnicas de regressão, demonstrou-se ser o $\mathrm{CO}$ o poluente que melhor explica a associação com um aumento de admissões hospitalares, sem apresentar o chamado "limiar de exposição", ou seja, um limite abaixo do qual não se observam influências com o evento de estudo. 0 mecanismo de ação do CO no aumento da morbidade coronariana prende-se à diminuição da oferta de oxigênio ao músculo cardíaco.

Em outro estudo epidemiológico, com metodologia semeIhante, acompanhou-se uma coorte de 107 crianças asmáticas (6-17 anos) por um período relativamente curto (um a dois meses?), através de medidas diárias do pico de fluxo expiratório (PFE) e sintomas (Cabral AL e col.). O PEF associou-se negativamente ao poluente $\mathrm{O}_{3}$ sem demonstrar efeitos diferenciados entre os subgrupos de diferentes gravidades de asma. Não há menção de associação entre poluentes e sintomas. Este trabalho foi realizado na zona urbana de São Paulo, onde predomina a poluição a material particulado. $\mathrm{O} \mathrm{O}_{3}$ é um potente irritante de vias aéreas e associa-se a um aumento das reatividade brônquica em suscetíveis, porém, outros gases como o $\mathrm{SO}_{2}$ e $\mathrm{NO}_{x}$ também atuam como irritantes. Possivelmente associações distintas entre os diversos poluentes que ocorrem de maneira sazonal dentro de uma mesma área podem gerar diferentes modelos de associação com os efeitos sobre as vias aéreas.

ASSOCIATION BETWEEN AIR POLLUTION AND CARDIOVASCULAR ADMISSIONS IN SÃO PAULO, BRAZIL.

Lin CA, Braga ALF, Conceição GMS, Pereira LAA, Kishi HS, Milani J r. R, Saldiva PH N. Laboratory of Experimental Air Pollution, School of Medicine, University of São Paulo, SP, Brazil.

This work focuses the relation between air pollution and hospital admissions due to ischemic cardiovascular illness (angina and acute heart infarction - ICI) in São Paulo City. Daily records of hospital admissions for people between 45 and 80 years were obtained from the $\mathrm{H}$ eart Institute of the University of São Paulo Medical School, from J anuary 1994 to December 1995. Daily measures of CO, SO, $\mathrm{PM}_{10}$ and ozone were obtained for the same period from the State Air Pollution Controlling Agency (C etesb) as well as weather variables obtained from Institute of Astronomy and Geophysics of the University of São Paulo. The analysis was made by Poisson regression techniques, controlled of time trend, weather and days of week. CO (2-days moving average) was the pollutant that exhibited the most robust association with cardiovascular admissions. The average levels of $\mathrm{CO}$ during the study $(5.2 \mathrm{ppm})$ were associated with $6 \%$ increase of $\mathrm{ICl}$. This association exhibited a linear behavior and did not disclose any evidence of safety threshold. The results of this study support the idea that air pollution promotes significant health effects in São Paulo.

GAS EXCHANGE ABNORMALITIES AT REST AND DURING EXERCISE IN PATIENTS WITH ASBESTOSIS.

Sette AA, Guimarães SML, Bagatin E, Terra Filho M, Rodrigues RT, Kawakama JI, Napoli L, Nery LE. Interinstitutional Group of Study of A sbestos Related Disorders - U nicamp, USP, Unifesp, São Paulo, Brazil.

In order to evaluated possible gas exchange abnormalities in patients with asbestosis, we obtained lung diffusion capacity (DLCO and DLCO/VA) and arterial blood gases at rest and during constant load submaximal exercise (bellow the lactate threshold). Seventeen male workers, 40 to 82 years old, of the fibrocement industry were studied. The diagnosis of asbestosis was based in the occupational history, chest X-ray (ILO, 1980) and high resolution computed tomography. Seven patients had altered spirometry (6 with obstructive dysfunction), and 5 of them were current smokers. By contrast, 9 of 10 patients with normal spirometry were non smokers or ex-smokers (2 test, $p=0.01$ ). We did not observe $\mathrm{PaCO}_{2}$ change, but reduction of $\mathrm{PaCO}_{2}$ was detected in 5 and increase of $\mathrm{P}(\mathrm{A}-\mathrm{a}) \mathrm{O}_{2}(>5 \mathrm{mmH} \mathrm{g})$ in 7 patients, during exercise. Also, DLCO was reduced in 6 subjects, but just three of them had concomitant $P(A-a) O_{2}$ increase ( 2 test; $p=0.30 \mathrm{NS}$ ). We conclude that in patients with asbestosis, DLCO at rest and variation of $P(A-a)$ $\mathrm{O}_{2}$ from rest to exercise are useful tests for the diagnosis of gas exchange abnormalities; however DLCO was not always predictive of such abnormalities. Other factors possibly implicated are: increase of areas of low, ventilation/ perfusion $(\mathrm{V} / \mathrm{Q})$ and/ or reduction of $\mathrm{PvO}_{2}$ in areas of low $\mathrm{V} / \mathrm{Q}$, during exercise.

EVALUATION OF BRONCHIAL INFLAMMATION IN QUARRY MINE WORKERS IN RIO DE JANEIRO BY INDUCED SPUTUM.

Lago P, Flores V, Ribeiro C, Araújo A, Lemle A, Lapa e Silva JR. Multidisciplinary Laboratory and Pulmonary Medicine Service, Clementino Fraga Filho University Hospital, Federal U niversity of Rio de J aneiro, Brazil.

Silicosis and other respiratory diseases can affect workers exposed to silica dust in the workplace. To investigate the hypothesis that occupational chronic bronchitis is a distinct health problem, we performed a transversal study in a population of quarry mine workers from three mines in Rio de J aneiro. Workers with different levels of exposure to silica dust were randomly included, after signing Informed Consent for sputum induction. Exclusion criteria were smoking, asthma or recent respiratory infections. Healthy volunteers not exposed to silica were also included for comparison. Sputum induction was performed and cytospins were stained with Diff-Q uik, differential cell counts of at least 400 non-squamous cells were performed. We present herein results of sputum differential count of 44 individuals, 33 from the mines (13 from the administrative offices and 20 from the production sectors) and 9 volunteers. Ten workers $(30.3 \%)$ had respiratory symptoms. We found increased neutrophilia in the sputum of the quarry mine workers as compared with controls $(21.0 \pm 17.3 \%$ vs. $0.8 \pm 1.1 \%$; $p<0.01)$. No differences were seen between administration and production sectors regarding sputum neutrophils $(21.3 \pm 19.0 \%$ vs. $18.3 \pm 15.5 ; p>$ $0.05)$. Neutrophilia was higher in workers exposed over 5 years to silica $(16.2 \pm 15.4 \%$ vs. $24.8 \pm 19.2 \% ; p<0.05)$. We conclude that signs of bronchial inflammation are present in quarry mine workers, regardless of the area they work. This inflammation is also related to the time of dust exposure in years and could be a component of the chronic bronchial inflammation that affects these workers. 
PULMONARY MECHANICS, HISTOPATHOLOGY AND LYMPHOCYTE APOPTOSIS IN A MURINE MODEL OF SILICOSIS.

Falcão H, Leite-J únior J HP, Ciminelli PB, Borges VM, Lopes MF, DosReis GA, Rocco PRM, Zin WA. Laboratories of Respiration Physiology and Immunology Biology, Carlos Chagas Filho Biophysics Institute, Federal U niversity of Rio de J aneiro, RJ , Brazil.

Pulmonary mechanics and histopathology from BALB and BALb. GLD [deficient in functional Fas (CD95) Ligand] mice were analyzed 15 days after intratracheal instillation of saline or silica $20 \mathrm{mg}$ per mouse]. Mice were ventilated with constants' flow and volume, and PEEF (2 $\left.\mathrm{cmH}_{2} \mathrm{O}\right)$. Static (Est) and dynamic (edyn) elastances resistive (P1) and viscoelastic/ inhomogeneous pressures (P2) were obtained. In BALB group, Est, Edyn, P1 and P2 increased (31\%, 37\%, 421\% and $81 \%$, respectively) in relation to saline group. In addition, histologic evaluation revealed interstitial and alveolar edema, accumulations of cells mainly polymorphonuclear, alveolar collapse and intrabronchial cellular infiltration obstructing the lumen. However, in BALB. GLD, we observed no changes in pulmonary mechanics and histopathology. Pulmonary BALB lymph nodes were enlarged, containing increased numbers of macrophages and activated CD4+ and CD8+ T cells, by flow cytometry. Treating pulmonary lymph node cells with anti-TCR; CD3 resulted in CD4+, but not CD8+ T-cell death, and in DNA fragmentation. We conclude that silica inhalation led to elastic, resistive and viscoelastic pulmonary changes that are related to neutrophil infiltration, intrabronchial obstruction and alveolar collapse in mouse lung. There was immune stimulation and activation-induced cell death of CD 4 + T lymphocytes draining silica-laden macrophages. The Fas/ FasL death pathway appears critically involved in induction of pulmonary tissue damage.

MECHANICAL BEHAVIOR AND STRUCTURAL COMPOSITION OF LUNG PARENCHYMAL STRIP IN A MURINE MODEL OF SILICOSIS.

Silva GH, Faffe DS, Kurtz PMP, Rocco PRM, Zin WA. Laboratory of Respiration Physiology, Carlos Chagas Filho Biophysics Institute, Federal U niversity of Rio de J aneiro, Brazil.

Recently, mice have been extensively used to investigate the pathogenesis of silicosis because appropriate murine models are being increasingly developed. However, the dynamic properties of normal and silicotic mouse lung tissue, characterized by parenchymal strips studies, have not been previously performed. Resistance $(R)$, elastance $(E)$ and hysteresivity $(\eta)$ were analyzed during sinusoidal oscillations of BALB/ c mice (25-30 g) parenchymal strips 15 days after intratracheal instillation of saline [C, $(50 \mu \mathrm{g})]$ or silica [Sil, $(20 \mathrm{mg}$ per mouse)]. In addition, tissue strips were examined morphometrically in order to determine its anatomic constitution (the relative amounts of small vessels, airways, and alveolar walls) and cellularity. Strips (10 × $3 \times 3 \mathrm{~mm})$ were cut from the subpleural edge of the left lung. The wet weight and unstressed resting length (Lo) of each strips were recorded. The strips were suspended in an organ bath filled with Krebs solution bubbled with $95 \% \mathrm{O}_{2}-5 \% \mathrm{CO}_{2}$, and maintained at $37 \stackrel{\circ}{\circ}$. O ne end of the strip was attached to a force transducer and the other end to a lever system that effected length changes. The strips were oscillated at resting tension, amplitude of $5 \% \mathrm{~L}_{0}$, and various frequencies $(0.03,0.1,0.3,1$ and $3 \mathrm{~Hz}$ ). $\mathrm{O} n$ the basis of tension vs length curves, $E, R$, and $\eta$ were computed. At the end of the experiment, the strips were fixed in Carnoy at resting tension. Among Sil and C strips, E increased linearly with the logarithm of frequency, whereas $R$ decreased hyperbolically with frequency. $\eta$ was significantly higher at $0.03 \mathrm{~Hz}$, remaining unaltered with increasing frequencies. Sil strips presented $\mathrm{R}$ and $\mathrm{E}$ higher than $C$, independently of frequency. $\eta$ was similar in both groups. Sil and $C$ strips had similar anatomic constitution. Cellular infiltration in Sil strips correlated with functional changes.

\section{POLUIÇÃO}

\section{ACUTE EFFECTS OF INHALABLE PARTICLES ON MUCOCILIARY} EPITHELIUM.

Macchione M, Oliveira AP, Gallafrio CT, M uchão FP, O bara MT, G uimarães $E T$, A rtaxo $P$, King $M$, Lorenzi-Filho $G$, J unqueira VCB, Saldiva PHN. Laboratory of Experimental Air Pollution, School of Medicine, Physics Institute, Chemistry Institute, University of São Paulo, Brazil, Pulmonary Research Group, Department of Medicine, University of Alberta, Edmonton, Canada.

This work was designed to evaluated by different parameters the toxicity of inhalable particles $\left(\mathrm{PM}_{10}\right)$ collected from the urban air in São Paulo, Brazil, to the mucociliary apparatus using the frog palate preparation. Two groups of frog palates were immersed in Ringer (control) and $500 \mu \mathrm{g} / \mathrm{m}^{3}$ of $\mathrm{PM}_{10}$ diluted in Ringer during 120 minutes were studied by means of morphometric analyses (quantification of the amount of intraepithelial and surface mucins), measurement of cilia beat frequency $(C B F)$ and quantification of total glutathione $(G S H)$. Exposure to $\mathrm{PM}_{10}$ elicited a significant depletion of neutral intraepithelial mucins (NM) ( $p=0.0461)$, and decrease of GSH $(p=0.003)$. These results showed that $\mathrm{PM}_{10}$ can promote significant alterations in ciliated epithelium in vitro. These effects are at least in part mediated by oxidative stress.

THE INFLUENCE OF TEMPERATURE AND LENGTH OF TIME OF STORAGE OF NORMAL HUMAN MUCUS SAMPLES ON TRANSPORT.

Gastaldi AC, Zanchet RC, J ardim J R. Physiotherapy Graduation Course of Centro Universitário do Triângulo, Respiratory Division of Federal University of São Paulo, Brazil.

Introduction: frozen stored human mucus have been extensively used for transport studies. It was demonstrated for frog mucus, but for human mucus there is no clear evidence of the influence that the temperature and length of time of storage may have on the results. Methods: we collected mucus from endotracheal tube from 15 subjects without pulmonary disease and stored their mucus samples at minus 20 and $18^{\circ} \mathrm{C}$ and analyzed them on days zero and 90 . We studied the relative transport velocity on frog palate and contact angle measurements. Results: the means for relative transport velocity and contact angle were 1.16 and 28 degrees for fresh samples (day zero). At the $90^{\text {th }}$ day, the means were 0.97 and 29 degrees for minus $80^{\circ} \mathrm{C}$ and 0.99 and 29 degrees for minus $20^{\circ} \mathrm{C}$. A nalysis of variance did not show any significance among days or temperatures $(p<0.05)$. Conclusion: we conclude that normal human mucus can be stored at minus 20 or $80^{\circ} \mathrm{C}$ for a period up to 90 days without difference for ciliary transport or contact angle measurement.

\section{THE EFFECTS OF FORMALDEHYDE ON THE CILIATED EPITHE-} LIUM.

Fló-N eyret C, Lorenzi-Filho G, Saldiva PHN. Dept. of Pathology, U niversity of São Paulo, Federal University of São Paulo, Brazil.

The use of biomass fuels for automotive purposes has been considered as a clean alternative for the increase of air pollution levels in large cities. Methanol and ethanol are being used in large scale in Brazil for the past 20 years. The proper toxicological evaluation of the components derived from the incomplete burnt of fuel into the engines, such as aldehydes, is mandatory. This work was designed to evaluate the effects of formaldehyde on the ciliated epithelium using the frog palate preparation. Four groups of frog palates were immersed in different concentrations of formaldehyde diluted in Ringer during 60 minutes: 0 (control), 1.25, 2.5 and 5 ppm. Mucociliary Transport $(\mathrm{MT})$, cicliary beating frequency (CBF) were determined at $0,15,45$ 
and 60 min. After 60 min both MT and CBF decreased significantly in the groups 2.5 and $5 \mathrm{ppm}(\mathrm{p}<0.05)$. We conclude that formaldehyde affects, at relatively low concentrations, the clinical mucosa after short term exposures.

ASSOCIATION BETWEEN AIR POLLUTION AND PEAK FLOW MEASUREMENTS IN CHILDREN IN SÃO PAULO, BRAZIL.

Cabral AL, Conceição GMS, Pope CA III, Saldiva PHN, Martins MA. Laboratory of Experimental Air Pollution, School of Medicine, University of São Paulo, Brazil.

The present investigation was designed to evaluate the possible association between urban levels of air pollution and decrement of pulmonary function in asthmatic children. For this purpose, a cohort study was performed involving 107 asthmatic children, aged 6 to 17 years, attending a referral center for asthma management in São Paulo. They were followed from May to J une, 1995. Daily values of $\mathrm{O}_{3}$ (maximum hourly level), $\mathrm{CO}$ (maximum 8 hours moving average), $\mathrm{SO}_{2}, \mathrm{NO}_{2}$ and inhalable particles $\left(\mathrm{PM}_{10}\right)$ (24 hours mean) were obtained from 12 air pollution measuring stations, dispersed across the town. In addition, daily measurements of temperature and relative humidity were collected for the same period. Peak expiratory flow (PEF) measurements (morning and evening), and asthma symptoms were recorded daily for each child in a diary. The relationship between PEF and pollution was investigated by time series modeling, taking into account not only pollution levels but also different possibilities for weather and seasonal effects. Statistical calculations were done using the autoregressive procedure of the SAS package. PEF was negatively associated with $\mathrm{O}_{3}$ levels up to the preceding 5 days. In average, we observed a decrement of 0.08 (standard error of 0.0258 ) liters. $s^{-1}$ for each $\mu \mathrm{g} . \mathrm{m}^{-3}$ of ambient $\mathrm{O}_{3}$, or, in other words, a decrement of 2.8 liters $^{-1}$ if one considers the mean $\mathrm{O}_{3}$ levels ( 34.4 ug. $\mathrm{m}^{-3}$ ) observed in São Paulo during the period of study. The effects of $\mathrm{O}_{3}$ on PEF were not affected by the severity of asthma (mild, moderate and severe). As defined by the International Consensus Report on Asthma Diagnosis and Treatment, our results support the concept that urban air pollution exhibits a deleterious effect on pulmonary health in asthmatic children. 